\title{
PERFORMANCES AND SENSORY QUALITY OF BROILERS FED WITH DIFFERENT LEVELS OF EXTRUDED RAPESEED MEAL
}

\author{
D. Milić ${ }^{1}$, V. Stanaćev ${ }^{1}$, V. Stanaćev ${ }^{2}$, N. Milošević ${ }^{2}$ N. Puvača ${ }^{2}$, N. \\ Džinić ${ }^{3}$, Z. Škrbićc
}

\footnotetext{
${ }^{1}$ Perutnina Ptuj - Topiko a.d., Petefi Brigade 2, 24300 Bačka Topola, Republic of Serbia.

${ }^{2}$ Faculty of Agriculture, University of Novi Sad, Department of Animal Science, Trg Dositej Obradović 8, 21000 Novi Sad, Republic of Serbia.

${ }^{3}$ Faculty of Technology University of Novi Sad, Bulevar Cara Lazara 1, 21000 Novi Sad, Republic of Serbia.

${ }^{4}$ Institute for Animal Husbandry, Autoput 16, P.Box 23, 11080 Belgrade, Republic of Serbia.

*Corresponding author: dragan.milic@perutnina.eu

Original scientific paper
}

\begin{abstract}
In this paper the effect of extruded rapeseed meal on the performance and sensory quality of the breast meat of broilers was investigated. The experiments were performed with hybrid line ROSS 308. The control group was fed soybean meal, and two levels of extruded rapeseed meal were added in experimental groups, $4 \%$ and $8 \%$ during a period of 42 days. Final body masses of chicken in the experimental groups were lower for $1.79 \%$ and $3.05 \%$ than the control group. Conversion of feed was satisfactory in all groups, and the best in the control group. Including extruded rapeseed meal in the meal did not show negative effect on the sensory quality, the smell and the colour, of fresh breast meat. Sensory quality (smell, taste and sensitivity) of heat-treated breast meat of the chickens in the control and experimental groups was marked as "very good", or optimal.
\end{abstract}

Key words: extruded rapeseed meal, broilers, nutrition, meat quality

\section{Introduction}

Protein rich feed is since long in deficit on the world market. Furthermore, the production of biodiesel could contribute to lessen the use of rapeseed meal in the nutrition of broilers (Leeson and Summers, 1997). Of course, detailed researches are needed to adapt the composition of nutrition for domestic animals and concerning the fact that this nutrition has not been used commercially. Rapeseed is an important source of oil and protein, but it contains compounds reducing the nutritive value such as cellulose and anti-nutritive metabolites erucic acid and glucosinolates. Actually, breeders could considerably reduce the content 
of anti-nutritive factors, so that the problem of anti-nutritive factors can be solved by choosing the variety of rapeseed in which the content of glucosinolate and erucic acid is minimal. However, one still has to be careful when the amount of this nutrition in complete mixture is in question (Nwokolo and Bragg, 1977; Paik and Robblee, 1980; Keith and Bell, 1987; Cmiljanić et al., 2001; Stanaćev et al., 2002; Stanaćev et al., 2003; Stanaćev and Kovčin, 2004; Stanaćev et al., 2005; Stanaćev, 2009; Stanaćev et al., 2011; Puvača, 2011). The nutritive value of rapeseed meal can be improved by the thermal process of extrusion which inactivates the enzyme myrosinase. (Sakač et al., 2004; Filipović et al., 2004; Filipović et al.,2010). Beside usual changes on the substrate as a result of thermal treatment, extrusion also changes functional characteristics of rations, and makes it possible to have the preferred texture of the final product (Pejić and Kovčin, 1995). The quality of meat is a very complex term as it is the result of numerous premortal and postmortal factors (Rede and Petrović, 1997). It is thought that the nutrition is a dominant factor, affecting for more than $30 \%$ the quality of carcass and meat (Rede and Petrović, 1997; Čepin and Čepon, 2001; Džinić, 2005).

Having in mind the importance of the content of food and that with extrusion the quality of animal feed is improved, the aim of the research was to examine the effect of the extruded rapeseed meal on the performances of hybrid line ROSS 308 broiler chickens and the sensory quality of the breast meat.

\section{Material and methods}

Biological researches are made in productive conditions on the farm "Pustara" in Temerin and in the laboratory of Technological Faculty in Novi Sad. In the 42 days experiment, chickens of hybrid line Ross 308 were used. The animals were put in three groups at random, weighed and put in boxes. The experiments were performed in four repetitions, on a total of 300 chickens in one treatment. Chickens were fed and watered ad libitum, and microclimatic conditions regularly controlled. Weighing was once a week. Two mixtures were used for nutrition (Table 1 and 2). For the first three weeks starter, and then finisher mixture until the end of the experiment from which in the last week salinomicine were taken out. Control group was fed with the mixture based on soybean meal, while in experimental groups there was $4 \%$ and $8 \%$ of extruded rapeseed meal. Mixtures were isoprotein and isoenergetic.

At the end of the experiment, eight chickens from every group was sacrificed, of average weight, to be used in the analysis of meat quality. Broilers were slaughtered after 12 hours of fasting and the following operations were taken: bleeding, scalding, plucking feathers and taking internal organs out, and also cooling. 
Table 1. Composition of starter feed mixture

\begin{tabular}{|l|c|c|c|}
\hline \multirow{2}{*}{ Corn } & I & II & III \\
\cline { 2 - 4 } & $\%$ & $\%$ & $\%$ \\
\hline Soybean meal & 48.59 & 47.74 & 45.78 \\
\hline Full fat soy & 29.00 & 26.00 & 23.00 \\
\hline Extruded rapeseed meal & 14.00 & 14.00 & 15.00 \\
\hline Yeast & 0.00 & 4.00 & 8.00 \\
\hline Soy oil & 2.50 & 2.50 & 2.50 \\
\hline Monocalcium phosphate & 1.50 & 1.50 & 1.50 \\
\hline Chalk & 1.30 & 1.20 & 1.20 \\
\hline Salt & 1.60 & 1.60 & 1.60 \\
\hline Methionine & 0.30 & 0.30 & 0.30 \\
\hline Premix & 0.21 & 0.16 & 0.12 \\
\hline Total & 1.00 & 1.00 & 1.00 \\
\hline
\end{tabular}

Table 2. Composition of finisher feed mixture

\begin{tabular}{|l|c|c|c|}
\hline & I & II & III \\
\cline { 2 - 4 } & $\%$ & $\%$ & $\%$ \\
\hline Corn & 54.70 & 53.35 & 51.90 \\
\hline Soybean meal & 23.50 & 21.00 & 17.50 \\
\hline Full fat soy & 14.00 & 14.00 & 15.00 \\
\hline Extruded rapeseed meal & 0.00 & 4.00 & 8.00 \\
\hline Yeast & 2.00 & 2.00 & 2.00 \\
\hline Soy oil & 1.50 & 1.50 & 1.50 \\
\hline Monocalcium phosphate & 1.30 & 1.20 & 1.20 \\
\hline Chalk & 1.50 & 1.50 & 1.50 \\
\hline Salt & 0.30 & 0.30 & 0.30 \\
\hline Methionine & 0.20 & 0.15 & 0.10 \\
\hline Premix & 1.00 & 1.00 & 1.00 \\
\hline Total & 100.00 & 100.00 & 100.00 \\
\hline
\end{tabular}

After cutting cooled carcasses and taking chest bones out, samples were taken from the breast muscles of the control and the experimental groups to determine sensory quality, with the sensory analysis of fresh and thermally processed breast meat. Analysis was done by 6 graders of different age. For sensory analysis of certain characteristics an analytical descriptive test was used with the system values from 1-7 as shown in Table 3 . The breast meat of every unit was thermally processed by baking at $175^{\circ} \mathrm{C}$ for 45 minutes. In order to have correct interpretation of the results, data were statistically processed by calculating: average $\left(\mathrm{x}^{-}\right)$, standard deviation (SD) and importance of the difference between averages (t-test) (Hadživuković, 1991). 
Table 3. Sensory analysis of fresh and thermally processed breast meat of chickens

\begin{tabular}{|c|c|c|c|c|c|c|}
\hline Mark & \multicolumn{2}{|c|}{ Fresh meat } & \multicolumn{4}{|c|}{ Thermal processed meat } \\
\hline & Smell & Colour & Smell & Taste & Juiciness & Gentleness \\
\hline 1 & $\begin{array}{l}\text { Extremely bad } \\
\text { (weak, not } \\
\text { prominent, } \\
\text { strange, } \\
\text { exaggerated) }\end{array}$ & $\begin{array}{l}\text { Extremely bad } \\
\text { (non suitable, } \\
\text { pale grey and } \\
\text { yellow or dark } \\
\text { with spotted } \\
\text { bleedings) }\end{array}$ & $\begin{array}{l}\text { Extremely } \\
\text { bad(weak, not } \\
\text { prominent, } \\
\text { strange, } \\
\text { overemphasiz } \\
\text { ed) }\end{array}$ & $\begin{array}{l}\text { Extremely } \\
\text { bad(weak, } \\
\text { not } \\
\text { prominent, } \\
\text { strange, } \\
\text { overemphas } \\
\text { ized) }\end{array}$ & $\begin{array}{l}\text { Extremely } \\
\text { bad } \\
\text { (very dry } \\
\text { or very } \\
\text { juicy) }\end{array}$ & $\begin{array}{l}\text { Extremely } \\
\text { bad } \\
\text { (very rough } \\
\text { or very } \\
\text { soft) }\end{array}$ \\
\hline 2 & Very bad & Very bad & Very bad & Very bad & Very bad & Very bad \\
\hline 3 & $\mathrm{Bad}$ & $\mathrm{Bad}$ & $\mathrm{Bad}$ & $\mathrm{Bad}$ & $\mathrm{Bad}$ & $\mathrm{Bad}$ \\
\hline 4 & $\begin{array}{l}\text { Not good, } \\
\text { not bad }\end{array}$ & $\begin{array}{l}\text { Not good, } \\
\text { not bad }\end{array}$ & $\begin{array}{l}\text { Not good, } \\
\text { not bad }\end{array}$ & $\begin{array}{l}\text { Not good, } \\
\text { not bad }\end{array}$ & $\begin{array}{l}\text { Not good, } \\
\text { not bad }\end{array}$ & $\begin{array}{l}\text { Not good, } \\
\text { not bad }\end{array}$ \\
\hline 5 & Good & Good & Good & Good & Good & Good \\
\hline 6 & Very good & Very good & Very good & Very good & Very good & Very good \\
\hline 7 & $\begin{array}{l}\text { Very good } \\
\text { (optimal, very } \\
\text { good, } \\
\text { pleasant, } \\
\text { gentle) }\end{array}$ & $\begin{array}{l}\text { Very good } \\
\text { (optimal, } \\
\text { bright red } \\
\text { with bright } \\
\text { shade of } \\
\text { yellow orange } \\
\text { colour) }\end{array}$ & $\begin{array}{l}\text { Very good } \\
\text { (optimal) }\end{array}$ & $\begin{array}{l}\text { Very good } \\
\text { (optimal) }\end{array}$ & $\begin{array}{l}\text { Very good } \\
\text { (optimal) }\end{array}$ & $\begin{array}{l}\text { Very good } \\
\text { (optimal) }\end{array}$ \\
\hline
\end{tabular}

\section{Results and discussion}

Based on the obtained results it can be stated that adding extruded rapeseed meal into the nutrition of broilers does not significantly affect the performance (Table 4). In the first period of fattening, with youngsters, differences are somewhat more prominent and increase with the increase of rapeseed meal addition (4\% and $8 \%)$ compared to the control group $(631.28 ; 592.43 ; 574.28)$. However, in the second period of fattening the differences are much smaller. The second group is behind the control group only by $38 \mathrm{~g}$, and the third by $64 \mathrm{~g}$, which in relative values is $1.79 \%$ and $3.05 \%$ compared to the control group. Our results are in concordance with research by Džinić et al. (2007), Milošević et al. (2011). The reason for this is probably the lower level of glucosinolate compared to old varieties, with which the weight reduction was even up to $25 \%$. 
Table 4. Body weight of broilers, $g$

\begin{tabular}{|c|c|c|c|}
\hline Group & I & II & III \\
\hline Level of rapeseed meal,\% & 0 & 4 & 8 \\
\hline Initial body weight & 41.02 & 41.07 & 41.48 \\
\hline week 1 & 129.58 & 123.53 & 121.79 \\
\hline week 2 & 352.01 & 333.13 & 333.67 \\
\hline week 3 & 631.28 & 592.43 & 574.28 \\
\hline Index,\% \%eek 4 & 100.00 & 93.84 & 90.97 \\
\hline week 5 & 1024.90 & 1022.80 & 973.47 \\
\hline week 6 & 1492.39 & 1412.01 & 1450.91 \\
\hline Index,\% & 2112.00 & 2074.20 & 2047.72 \\
\hline
\end{tabular}

Different addition of extruded rapeseed meal had effect on the feed conversion (Table 5). In the first period of fattening, the smallest and balanced feed conversion in groups I and II had $1.57 \mathrm{~kg} / \mathrm{kg}$ of growth. In the third group the conversion is $1.69 \mathrm{~kg} / \mathrm{kg}$ of growth. The most efficient usage of feed in the second period of fattening and for the whole experiment is in the control group (1.89 and $1.80 \mathrm{~kg} / \mathrm{kg}$ of growth), and from experimental, in group II with $4 \%$ of the extruded rapeseed meal $(1.82 \mathrm{~kg} / \mathrm{kg}$ of growth).

Table 5. Feed conversion, kg

\begin{tabular}{|l|c|c|c|}
\hline Group & I & II & III \\
\hline Level of extrude rapeseed meal,\% & 0 & 4 & 8 \\
\hline Stage I & 1.570 & 1.570 & 1.687 \\
\hline Index,\% & 100.00 & 99.94 & 107.45 \\
\hline Stage II & 1.892 & 1.927 & 2.019 \\
\hline Index,\% & 100.00 & 101.82 & 106.68 \\
\hline Average & 1.797 & 1.825 & 1.925 \\
\hline Index,\% & 100.00 & 101.57 & 107.11 \\
\hline
\end{tabular}

With the examination of the sensory quality of fresh breast meat (Table 6) we found no statistically significant difference $(\mathrm{P}>0.05)$ in the marks for certain sensory characteristics and that smell and colour of breast meat of chickens in the control group averagely marked as "good" to "very good". With the examination of thermally processed breast meat (Table 6) we found statistically significant differences $(\mathrm{P}<0.05)$ with higher mark 6.30 (very good) marked for smell of the experimental group with $4 \%$ of extruded rapeseed meal, compared to 5.52 (very good) for the third group of chickens with the $8 \%$ of the same feed.

Further in the same Table 6 it can be seen that breast meat of the control and experimental groups of chickens are graded with marks 6.27; 6.30 and 6.02 respectively for the taste, actually as of "very good taste". Sensor mark of juiciness of breast meat of chickens in the third group is 6.37 (very good) and it is 
significantly greater $(\mathrm{P}<0.05)$ than sensor mark of juiciness $(5.52)$ in the II group and (5.05) in the control group. The breast meat of chickens in the control and experimental groups are sensory graded as very gentle, or optimally gentle.

Table 6. Sensory quality of breast meat of chickens

\begin{tabular}{|c|c|c|c|c|c|c|c|}
\hline \multirow{2}{*}{$\begin{array}{l}\text { Qualities of sensor } \\
\text { quality }\end{array}$} & Mark & I & $\mathrm{I}$ & II & II & III & III \\
\hline & Groups & $\mathrm{X}$ & SD & $\mathrm{X}$ & SD & $\mathrm{X}$ & SD \\
\hline \multirow{2}{*}{ Fresh meat } & Colour & 5.80 & 1.02 & 5.48 & 0.48 & 5.90 & 0.50 \\
\hline & Smell & 5.69 & 0.48 & 5.78 & 0.33 & 5.83 & 0.30 \\
\hline \multirow{4}{*}{ Thermal processed meat } & Smell & $6.17^{\mathrm{a}}$ & 0.64 & $6.30^{\mathrm{a}}$ & 0.18 & $5.52^{\mathrm{b}}$ & 0.19 \\
\hline & Taste & 6.27 & 0.71 & 6.30 & 0.18 & 6.02 & 0.36 \\
\hline & Juiciness & $5.05^{\mathrm{b}}$ & 0.36 & $5.52^{\mathrm{b}}$ & 0.19 & $6.37^{\mathrm{a}}$ & 0.63 \\
\hline & Gentleness & 6.68 & 0.32 & 6.37 & 0.17 & 6.47 & 0.54 \\
\hline
\end{tabular}

ab $\mathrm{P}<0.05$

\section{Conclusion}

Based on the results presented it can be concluded that the chickens of the second and third group, that consumed feed with addition of extruded rapeseed meal, made somewhat weaker productive results compared to chickens of the control group. Final body masses were lower in experimental groups $1.79 \%$ and $3.05 \%$ in comparison to the control group. Conversion of feed is satisfactory in all groups, and the best one is in the control group of chickens.

Replacement of the part of standard meal for chickens with extruded rapeseed meal did not show negative effect on the sensory quality (smell and colour) of fresh breast meat. Sensory quality (smell, taste and gentleness) of thermally processed breast meat of chickens in the control and experimental groups is graded as "very good", or optimal.

We can conclude that extruded rapeseed meal is a feed of satisfactory quality and can be used for the nutrition of broilers in limited amounts, as substitution for other more expensive nutrients, without negative effect on productive parameters or on the sensory quality of the meat.

\section{Acknowledgments}

This paper is a part of the project TR-31033 which is financed by Ministry of Education, Science and Technological Development of Republic of Serbia. 


\title{
Performanse i senzorni kvalitet mesa brojlera hranjenih različitim nivoima ekstrudirane sačme uljane repice
}

\author{
D. Milić, V. Stanaćev, V. Stanaćev, N. Milošević, N. Puvača, N. Džinić, Z. \\ Škrbić
}

\section{Rezime}

U radu je ispitivan efekat ekstrudirane sačme uljane repice na proizvodne performanse i senzorni kvalitet mišića grudi brojlera. Ispitivanja su obavljena na pilićima hibridne linije ROSS 308. Kontrolna grupa je bila na bazi sojine sačme, a u oglednim grupama su korišćena dva nivoa ekstrudirane sačme uljane repice, 4\% i $8 \%$ u periodu od 42 dana. Završne telesne mase pilića u eksperimentalnim grupama su bile nešto niže i zaostajale za kontrolnom grupom 1,79 \% i 3,05\%. Konverzija hrane je bila zadovoljavajuća u svim grupama, a najbolja u kontrolnoj grupi pilića. Uključivanje ekstrudirane sačme uljane repice u obrok nije ispoljilo negativan uticaj na senzorni kvalitet (miris, ukus i nežnost) toplotno obrađenih mišića grudi pilića kontrolne i eksperimentalnih grupa je ocenjen kao "veoma dobar", odnosno optimalan.

\section{References}

CMILJANIĆ R., SRETENOVIĆ LJ., TRENKOVSKI S., MARINKOV G. (2001): Systems of poultry nutrition and their effect on production traits and quality of product. Biotechnology in Animal Husbandry, 17, 5-6, 179-185.

ČEPIN S., ČEPON M. (2001): Uticaj genetike i sredine na kvalitet junećeg trupa i mesa. Tehnologija mesa, 42, 283-284.

DŽINIĆ N. (2005): Uticaj endogenih i egzogenih faktora na kvalitet mesa svinja. Doktorska disertacija, Tehnološki fakultet, Univerzitet u Banja Luci, pp. 1-227. DŽINIĆ N., PETROVIĆ LJ., TOMOVIĆ V., TASIĆ T., FILIPOVIĆ S. (2007): Effect of partial substitution of standard meal in chicken feed by rapeseed on carcass and meat quality. Biotechnology in Animal Husbandry 23 (5-6), 323-329. FILIPOVIĆ S., KORMANJOŠ Š., SAKAČ M., FILIPOVIĆ J., PSODOROV Đ., OKANOVIĆ Đ. (2010): Effect of extrusion on nutritive value of animal feed. $2^{\text {nd }}$ Workshop FEED-TO-FOOD, FP7 REGPOT-3, $19^{\text {th }}-21^{\text {st }}$ October, 2010, Institute for Food Technology, Novi Sad, Serbia, Thematic Proceedings, 2, 97-116.

FILIPOVIĆ S., SAKAČ M., BOROJEVIĆ Č., RISTIĆ M., KORMANJOŠ Š. (2004): Tehnološki postupak ekstrudiranja uljane repice sa primarnim poljoprivrednim proizvodima. 45. Savetovanje "Proizvodnja i prerada uljarica", Zbornik radova, 45, 141-146. 
HADŽIVUKOVIĆ S. (1991): Statistički metodi. Drugo prošireno izdanje, Poljoprivredni fakultet, Univerzitet u Novom Sadu, Novi Sad, pp 1-584.

KEITH M., BELL J. (1987): Effect of canola meal on tissue trace mineral concentrations in growing pigs. Canadian Journal of Animal Science, 67, 133-140.

LEESON S., SUMMERS D. (1997): Commercial Poultry Nutrition. University books, Guelph, Ontario, Canada.

MILOŠEVIĆ N., STANAĆEV V., PERIĆ L., ŽIKIĆ D., ĐUKIĆ-STOJČIĆ M., MILIĆ D. (2011): Use extruded rapeseed meal in the feed of broiler chickens. Biotechnology in Animal Husbandry 27 (4), 1681-1687.

NWOKOLO E., BRAGG D. (1977): Influence of fytic acid and crude fiber on the availability of minerals from four protein supplements in growing chicks. Canadian Journal of Animal Science, 57, 475-477.

PAIK I., ROBBLEE A., CLANDININ D. (1980): Products of the hydrolysis of rapeseed glucosinolates. Canadian Journal of Animal Science, 60, 481-493.

PEJIĆ N., KOVČIN S. (1995): Ishranbeni efekti ekstrudiranja. Zbornik radova sa savetovanja "Naučna dostignuća u stočarstvu '95", Novi Sad, 35-49.

PUVAČA N. (2011): Ekstrudiranje i mikronizacija u preradi hrane za životinje. MSc teza, Poljoprivredni fakultet, Univerzitet u Novom Sadu, Serbija, pp 1-107.

REDE R., PETROVIĆ LJ. (1997): Tehnologija mesa i nauka o mesu. Tehnološki fakultet, Univerzitet u Novom Sadu, Novi Sad, pp 1-512.

SAKAC̆ M., FILIPOVIĆ S., BOROJEVIĆ C̆., RISTIĆ M., KORMANJOŠ S̆. (2004): Uticaj ekstrudiranja na sadržaj ukupnih glukozinolata uljane repice. 45. Savetovanje "Proizvodnja i prerada uljarica", Zbornik radova, 45, 133-140.

STANAĆEV V. (2009): Efekat zrna i sačme uljane repice u ishrani pilića. Magistarska teza, Poljoprivredni fakultet, Univerzitet u Novom Sadu, Srbija, pp 169.

STANAĆEV V., KOVČIN S. (2004): Parametri kvaliteta semena uljane repice. 45. Savetovanje "Proizvodnja i prerada uljarica", Zbornik radova, 45, 127-132.

STANAĆEV V., KOVČIN S., FILIPOVIĆ S., MILOŠEVIĆ N., BOŽIĆ A. (2005): Efekat sačme uljane repice u ishrani tovnih pilića. Savremena poljoprivreda, 54, 62-68.

STANAĆEV V., KOVČIN S., FURMAN T., NIKOLIĆ R., SAVIN L., TOMIĆ M. (2002): Hemijski sastav i hranljiva vrednost domaće sačme uljane repice. Traktori i pogonske mašine, $7,80-83$.

STANAĆEV V., KOVČIN S., MARINKOVIĆ R. (2003): Hemijski sastav sačme i pogače nekih sorata uljane repice. 44. Savetovanje "Proizvodnja i prerada uljarica", Zbornik radova, 44, 259-263.

STANAĆEV V., KOVČIN S., STANAĆEV V., PUCAREVIĆ M., PUVAČA N. (2011): Extruded canola seed in improving chicken fattening and fatty acid composition. Kuwait Journal of Science and Engineering, 38(1A), 71-80. 